\title{
President's Press
}

In case any of you read On Call or Hospital Doctor (I forget which it was before they amalgamated) and believe what you read, I should point out that I did not say what I was recently reported to have said to the House of Commons Select Committee, namely that the secrecy of Distinction Awards should be maintained. It was in fact $\mathbf{M r}$ David Bolt, the Chairman of the Central Committee of Hospital Medical Services (CCHMS) of the BMA, who said this, and I do not agree with him. On the whole, I think more good than harm would come from information being available; but I don't think anyone should ever use his award as part of the subscript to his signature along with his degrees (as a member of our College once did-and probably others equally unwisely).

Whether the mechanism of making the Awards needs changing is, of course, another question, and I am not sure whether the publication of names would affect their allocation. The problem of promotion at stages in people's careers that are beyond the conventional examination techniques is common in many professional situations; for example, the choosing of Fellows from Members of a learned body. Promotion in the academic sphere also needs to take into account in varying proportions recognition for research work done, potential for the future, teaching and administrative ability and so on. One should also take into account the dubious validity and cost effectiveness of some extremely elaborate procedures, for example lengthy interviews and time-consuming questionnaires. In most instances there is a right and proper wide canvassing of opinions, but inevitably decision by consensus means that the safe man is more likely to get in than the brilliant maverick. Particular difficulties arise when, shall we say, there is one place and two candidates who are both worthy, but in utterly disparate ways. For example, how can one weigh one against the other when the first is a brilliant young academic clinician who has already made significant research and teaching contributions and the second is an older man who has borne the heat and burden of the day with an otherwise not very distinguished group of colleagues, maintaining standards of clinical care and teaching largely unaided, or even actively hampered by the situation he is in.

I was interested to hear one of the junior doctors at the session of the House of Commons Select Committee say very clearly that he thought the skew distribution of Distinction Awards between the specialties in no way affected recruitment. One has to remember that the higher awards are going to men and women who made their choice of specialization perhaps thirty years ago when things looked very different from now. As so often happens, W. S. Gilbert's social satire is curiously up-to-date. It was 100 years ago, a few years after the implementation of the famous Trevelyan Report on Entry into the Civil Service by Examination, that he wrote the line in Iolanthe 'Entry to the House of Lords by competitive examination'. Sullivan's sugary tunes have enabled generations of Establishment figures to accept with pleasure many acid comments on their society which would have outraged them had they been dressed up in some straight play with a message.

Turning to another subject, I should like to commend the regular series of interesting commentaries that Professor Rudolf Klein writes in the $B M J$ and elsewhere. His father was my first important teacher in psychiatry (and Dr Donal Early's), so I feel I am benefiting from the second generation of Kleinian analysis (Melanie was definitely no relation, however!). I particularly liked the recent comment he made that during economic growth governments like to emphasize the directive task, thus allowing ministers to claim credit for improvements; whereas in periods of pessimism about the economy governments pursue 'policies of blame diffusion' by emphasizing the importance of local decision-making, so that the central authority can disclaim responsibility for the bad news. The downward devolution of decision-making means that responsibility for maintaining the standards of service falls increasingly into the hands of all of us and we must be prepared to put up with what may seem to be unjustified criticism. We need to take full advantage of our College's traditionally strong local Divisions in keeping an eye on Health Service decisions, and lobbying local MPs, Community Health Councils, etc. All the Royal Colleges' roles in this way will have to increase, but perhaps especially those like ourselves and the Royal College of General Practitioners who are concerned with the services in the community rather than hospital-based ones. Community services represent a complicated interaction of local authority, Health Department and voluntary organizations, often without any mechanism for joint planning. We know this only too well, for example, in the field of the psychiatry of old age, and it behoves us to make ourselves friends of the mammon of unrighteousness (as we might feel from our professional ivory towers) if we are to get the service our patients deserve.

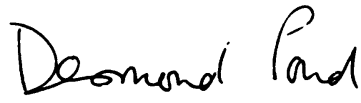

